\title{
TELAAH KONSEPTUAL PENDIDIKAN BARAT DAN ISLAM
}

\author{
Ifa Nurhayati \\ Program Studi Pendidikan Guru Madrasah Ibtida'iyah, Universitas Islam Raden \\ Rahmat (UNIRA) Malang \\ Email. Ifanurhayati12@gmail.com
}

\begin{abstract}
ABSTRAK
Tulisan ini bertujuan ingin mendeskripsikan perbedaan konseptual Pendidikan Barat (Umum) dan Pendidikan Islam. Berdasarkan hasil analisis yang telah dilakukan dapat disimpulkan bahwa perbedaan paradigma pendidikan Barat dan Islam tidak hanya terbatas pada ranah ontologis dan epistemologisnya, tetapi juga pada ranah aksiologis. Pada ranah ontologis, perbedaan pendidikan terlihat terutama pada ruang lingkup dan hakikat pendidikan itu sendiri. Pada ranah epistemologis, perbedaan keduanya terletak pada sumber pengetahuan yang dicari serta cara dan strategi untuk menggali sumber pengetahuan itu. Ranah konseptual ontologis hingga proses pendidikan (epistemologis) yang berbeda akan berpengaruh secara langsung pada tataran aksiologinya. Secara aksiologis, Pendidikan Barat tidak menjadikan nilai-nilai sebagai bagian dari hasil pendidikan, sementara Islam basis nilai manjadi sebuah keniscayaan dan bagian yang tak terpisahkan dari hasil pendidikan itu sendiri.
\end{abstract}

Kata Kunci: Ontologi, Epistemologi, Aksiologi, Pendidikan, Islam, Barat

\section{PENDAHULUAN}

Barat dan Islam di mata para pemerhati pendidikan adalah dua entitas peradaban yang secara spesifik memiliki ruang budaya sendiri-sendiri, baik dalam tataran sikap, cara pandang maupun pola hidup yang menjadi pilihannya. Lebih riil, perbedaan ruang budaya itu terutama terlihat dalam semua sikap, cara pandang maupun model paradigmatik pendidikan yang dikembangkannya.

Fakta sosiologis menyatakan bahwa pendidikan Barat acapkali membuahkan sikap keterbukaan, kemandirian, kebebasan, keberanian, dinamis-transformaif, dan kreatif. Sementara pendidikan Islam dalam faktanya acapkali menampakkan karakter sebaliknya, model pendidikan yang dikembangkan selalu mengantarkan hasil peserta didik yang tertutup, tidak mandiri, terkungkung pada muatan nilai, penakut, dan selalu menganggap sesuatu secara pasif-finalistik. Tentu, fenomena sosiologis dari keduanya tidak bisa dipisahkan dari cara pemahaman terhadap sistem nilai yang melatari keduanya.

Barat yang terinspirasi oleh sistem nilai hasil rekostruksi pemahaman pakar sebelumnya, dianggap masih banyak ruang dan peluang dilakukan reformulasi dan 
rekonstruksi secara kritis sesuai dengan semangat zamannya ${ }^{1}$. Sementara Islam yang sangat kuat berpegang pada sistem nilai normatif-doktrinal dianggap tidak terdapat ruang lagi bagi pemahaman dan penafsiran baru sesuai dengan zamannya. Padahal idealnya tidaklah demikian.

Sistem nilai dalam Islam harus menzaman, berkolaborasi dan berdialektik secara simultan terhadap perubahan dan perkembangan zaman. Atas dasar inilah mengapa pendidikan Islam acapkali tidak membuahkan hasil sesuai dengan tuntutan ideal yang tergambar dalam ajaran Islam secara universal? Tulisan ini akan mengkaji perbedaan komparatif pendidikan Barat dan Islam dari tiga ranah pemahaman filosofis, yaitu ranah ontologis, epistemologis, dan aksiologis.

\section{PEMBAHASAN}

\section{A. Perbedaan Konseptual (ontologi) Pendidikan Barat dan Islam}

Secara konseptual kedua entitas peradaban di atas (Barat dan Islam) memiliki cara pandang dan tekanan pemahaman yang sangat berbeda terhadap masalah pendidikan. Perbedaan itu tidak saja karena perbedaan sistem penalaran masing-masing oleh karena konteks sosio-kultural yang melingkupinya, namun perbedaan keduanya terlihat terutama karena pemahaman terhadap ruang lingkup muatan pendidikan, hakikat pendidikan, dan tujuan akhir pendidikan itu sendiri. Bagi Barat, ruang lingkup pendidikan hanya dibatasi pada aspek-aspek dhohir (alsyahaadah) yang Nampak (empirik-positifistik). ${ }^{2}$

Ruang lingkup muatan pendidikan bagi Barat, hanya dibatasi pada muatan pendidikan yang bisa dipelajari, difahami, dan dihayati secara empirik dan dibuktikan secara inderawi karena keberadaannya yang kasat mata. Ruang lingkup muatan pendidikan adalah ruang lingkup yang bisa dinalar oleh logika anak didik secara logis-sistematik-rasionalistik, tanpa menyentuh ruang lingkup lain yang bersifat intuitif-emosionalistik, yaitu ranah-ranah batin, hati, dan mental.

Karena itulah pendidikan agama, etika maupun moral di Barat sengaja tidak diajarkan secara terstruktur dalam materi kurikulum tertentu. Bagi Barat hakikat pendidikan tidak berhubungan secara langsung dengan nilai etik dan moral yang lebih bersifat emosional. Pendidikan hanya difahami sebagai upaya pendewasaan

\footnotetext{
${ }^{1}$ Muhaimin. Rekonstruksi Pendidikan Islam, Dari Paradigma Pengembangan, Manajemen Kelembagaan, Kurikulum hingga Strategi Pembelajaran (Jakarta; Raja Grafindo Persada, 2009)

2Murtadha Muthahhari, Tema- Tema Penting Filsafat Islam,Terj.A. Rifa'i Hasan dan Yuliani L (Bandung: Mizan, 1993), hal.25
} 
anak didik yang sanggup mengantarkan mereka menghadapi hidup dan kehidupan yang profan ini.

Hakikat pendidikan Barat selain hanya dibatasi pada ranah dhohir, pendidikan Barat juga hanya berorientasi pada kedewasaan dunia dan mengesampingkan akhirat. Peserta didik hanya diajak berpikir secara sadar pada objek-objek yang bersifat material-positifistik. Pemahaman ontologis yang demikian tentu akan mengantarkan arah dan tujuan pendidikan mereka yang sangat sekuler. Urusan moral, etika, dan agama bagi mereka tidak dikait-kaitkan dengan kehidupan publik. Agama bagi mereka adalah urusan yang sangat privat (individu). Sebab agama bagi mereka acapkali berseberangan dengan cara pandang dunia provan ini. Agama bagi anggapan Barat dalam faktanya banyak menghalang-halangi proses kemajuan penalaran dan pembangunan. Sehingga pada sisi tertentu agama harus dinegasikan dari kehidupan publik mereka.

Sementara itu model pendidikan Islam tidaklah demikian. Model pendidikan dalam Islam adalah pendidikan yang mutlak berdasarkan pada paradigma sistem nilai-nilai keagamaan, etika, dan moral. Pendidikan apapun coraknya, termasuk pendidikan umum, selalu saja sarat dengan basic nilai. Model pendidikan yang di dalamnya sengaja ditanamkan nilai-nilai al-akhlaq al-karimah. Oleh karena itu konsepsi pendidikan Islam adalah konsepsi pendidikan yang menyentuh dua domain sekaligus, yaitu domain fisik maupun psikis, dhohir maupun batin, jasmani maupun ruhani, sebagaimana tujuan pendidikan nasional kita.

Dengan demikian ruang lingkup objek pendidikan Barat dan Islam, sangatlah berbeda jauh, bagaikan langit dan bumi. Tentu yang demikian ini, akan melahirkan perbedaan cara pandang ukuran keberhasilan pendidikan di antara kedua peradaban di atas. Pada satu sisi keberhasilan pendidikan hanya dinilai dari kaca mata fisik, materi, yang tampak, dan profan, sementara di sisi lain ukuran keberhasilan pendidikan harus dipandang dari dua sudut secara bersamaan, yaitu fisik maupun psikis.

Perbedaan ruang lingkup objek pendidkan sebagaimana di atas, efeknya bagi paradigma pendidikan secara makro tidaklah sesederhana yang kita bayangkan. Perbedaan ruang lingkup objek pendidikan itu akan berefek pada konstruksi kurikulum secara umum, baik dilihat dari tujuan pendidikan, strategi/ model pembelajaran, materi/muatan yang diajarkan, maupun langkah evaluasi yang direncanakan. Perbedaan konseptual pendidikan Barat dan Islam lebih detil dapat diamati pada perbedaan konstruksi kurikulumnya, terutama yang menyentuh pada 
ranah epistemologi, yaitu berhubungan dengan sumber/materi yang ditanamkan dan strategi/cara untuk mencapai hakikat materi itu guna mengantarkan kedewasaan peserta didik.

\section{B. Perbedaan Proses Berfikir (epistemologi) Pendidikan Barat dan Islam}

Secara epistemologis, pendidikan Barat dan Islam bisa dibedakan dari dua instrument mendasar, yaitu instrument sumber pengetahuan dan instrument cara/strategi menggalinya. Berhubungan dengan intrumen sumber pengetahuan atau materi, epistemologi akan berbicara tentang dari mana sumber pendidikan itu di peroleh, dan meliputi apa saja sumber pendidikan itu diadaptasi. Sementara itu yang berhubungan dengan instrument cara/strategi, epistemologi akan berbicara tentang bagaimana cara, strategi, dan proses efektif mentransfer sumber pengetahuan atau materi pendidikan tersebut ke dalam karakter peserta didik.

Perbedaan epistemologi Barat dan Islam tentang instrument sumber pengetahuan terlihat sangat menonjol. Sumber pengetahuan atau materi pendidikan Barat lebih menekankan pada aspek pengalaman kehidupan secara empirik. ${ }^{3}$ Pengalaman kehidupan empirik yang dipandang banyak memberikan arti dalam kehidupannya dianggap sebagai sumber inspirasi kehidupan yang bisa diulangulang, sejauh belum ada sumber inspirasi kehidupan lain yang dinilai memiliki nilai lebih.

Sumber inspirasi kehidupam inilah yang secara tidak langsung oleh Barat dijadikan sebagai sistem nilai/pedoman (pattern for behavior) bagi proses kehidupan mereka. Bagi Barat tidak ada sistem nilai yang baku atau sakral. Pilihan mereka pada sistem nilai yang menjadi pedoman hidupnya bukan didasarkan pada nilai sakralitas yang bersifat supra natural tetapi lebih didasarkan pada nilai-nilai provan/ empirik yang bersifat natural. Oleh karena itu sumber atau materi yang dipedomani Barat acapkali mengalamai perubahan-perubahan signifikan sesuai dengan buktibukti empirik mana yang banyak memberikan konstribusi pada mereka.

Sedangkan sumber pengetahuan yang memberikan inspirasi dalam Islam adalah sumber nilai pengetahuan yang memiliki kebenaran universal, yaitu tek suci al-Qur'an dan al-Hadits, termasuk kata-kata hikmah dari para arif. Sumber nilai pengetahuan yang bukan berasal dari konstruksi pakar maupun elit masyarakat, melainkan dari pencipta alam semesta secara langsung. Sumber pengetahuan yang

${ }^{3}$ Atho Mudzhar, H.M,. Pendekatan Studi Islam, Dalam Teori dan Praktek (Yogyakarta, Pustaka Pelajar, 1998). 
memiliki kekuatan doktrin moral maupun etik kepada manusia. Inilah yang membedakan dengan Barat.

Sumber pengetahuan yang terjadi di Barat kering dari aspek sakralitas, sementara Islam sarat dengan muatan-muatan kesucian dan kesakralan. Dari aspek sumber pengetahuan, antara Barat dan Islam telah terlihat adanya perbedaan yang sangat menonjol. Perbedaan itu akan lebih Nampak lagi ketika dilihat dari aspek cara maupun strategi mendapatkan pengetahuan atau proses transfer knowledge, dari sumber pengetahuan hingga cara mendapatkannya.

Belakangan ini perkembangan teknologi dan informasi telah menunjukkan sedemikian kemajuannya. Beberapa efek maupun pengaruh dari keduanya, baik pengaruh positif maupun negatif tidak bisa lagi diprediksi oleh penggunanya. Bahkan karena melalui kemajuan keduanya, proses transfer knowledge pun kini tidak jarang telah menegasikan peran seorang guru atau pendidik secara langsung. Perang guru maupun pendidik secara langsung dalam kelas bisa digantikan dengan kecanggihan teknologi modern. Anak didik tidak lagi banyak tergantung dengan guru. Mereka mampu belajar mandiri tanpa seorang guru/dosen dalam kelas. Sudah tersedia teknologi modern yang secara lebih efektif dan efesien melebihi peran guru. cara inilah yang banyak mewarnai tradisi pendidikan Barat.

Secara logika rasional strategi transfer knowledge seperti ini sementara waktu banyak diminati oleh para pakar maupun pemerhati pendidikan. Hanya saja tanpa terasa cara ini telah mengesampingkan nilai-nilai esensial dari pendidikan itu sendiri. Nilai-nilai esensial itu ialah nilai etik dan moral yang acapkali muncul pada saat terjadi gesekan dialektik antara spirit penstransfer pengetahuan dan penerima pengetahuan itu. Pada saat itulah ada proses instituasionalisasi dan internalisasi nilai pada diri anak didik dan pendidik. Sebab semua pengetahuan yang ditransfer mensaratkan adanya pengendalian dan tanggungjawab moral untuk menjaganya.

\section{Perbedaan Aksiologis Pendidikan Barat dan Islam.}

Sejak awal tulisan ini mengatakan bahwa perbedaan paradigma pendidikan Barat dan Islam tidak saja terjadi pada aspek perbedaan ontologi dan epistemologi, namun juga pada ranah aksiologi. Hubungannya dengan pendidikan, aksiologi berbicara pada aspek kontribusi langsung pendidikan bagi masyarakat. Sudahkah kualitas pendidikan melahirkan manusia-manusia yang memiliki kesadaran secara holistik? Benarkah pendidikan akan melahirkan sebuah peradaban yang tinggi?

Idealnya arah dan tujuan pendidikan memang demikian. Hampir semua harapan masyarakat memiliki kesamaan cara pandang, bahwa masyarakat yang 
semakin tinggi kualifikasi pendidikannya masyarakatnya semakin maju. Namun demikian fakta sosiologis menunjukkan sebaliknya. Banyak pakar hukum yang menjalani hukuman, memainkan dan merekayasi hukum, banyak akuntan, ekonom yang korup, banyak pejabat yang kolusi, banyak orang pinter tapi keblinger. Statemen ini sederhana tetapi hal demikian sudah menjadi tradisi yang terlanjur memasyarakat. Mengapa demikian? Tentu ini semua tidak terlepas dari sumber pengetahuan apa saja yang berhasil diadaptasinya dan strategi bagaimana yang digunakan untuk menggalinya.

Untuk itu dalam rangka merealisasikan tujuan pendidikan, Islam selalu mengkait-kaitkan secara menyeluruh terhadap ketiga ranah di atas, yaitu ranah ontologi, epistemologi dan aksiologi. Atas dasar itu sudah menjadi rumus mutlak dalam islam, bahwa semakin tinggi status pendidikan seseorang maka semakin tinggi pula kesadaran moralitasnya. Oleh sebab itu membangun kesadaran moralitas dan spiritualitas tidak hanya terpusat pada pengurasan tenaga untuk melaksanakan upacara peribadatan, kegiatan di masjid dan membacaan al-Qur'an, sebagaimana tampak pada sebagian orang.

Mengingat tujuan pendidikan dalam Islam adalah membentuk manusia yang sempurna (insan kamil), sebagaimana yang tercakup dalam tujuan akhir pendidikan Islam, maka seluruh kegiatan pendidikan harus mencerminkan dan mempertimbangkan aspek-aspek kesadaran etik, moral dan spiritual. Pendidikan Islam telah menjunjung tinggi dan mengarahkan tujuan itu kepada arah ideal, sehingga pendidikan terhindar dari penyimpangan atau ketergelinciran, mengabdi kepada kemanusiaan serta mewujudkan kebahagiaan individu dan masyarakat.

1. Islam dan Perealisasian Kepribadian

Tujuan pendidikan ini merupakan faktor paling menonjol yang membedakan negara-negara Barat dengan Negara sosialis. Juga merupakan perkara paling menonjol yang banyak dibicarakan oleh Sir Bersey Nan. Sir mengatakan;

Perenialisasian kepribadian adalah tujuan akhir yang diusahakan secara maksimal dapat dicapai oleh pendidikan. Tidak ada suatu kebaikan pun yang mungkin diperoleh dunia ini, kecuali dengan jalan memberikan aktivitas mutlak bagi setiap individu, baik laki-laki maupun perempuan. Dan bahwa pendidikan yang menjadikan prinsip 'perealisasian kepribadian' sebagai tujuannya adalah satu-satunya pendidikan yang 
berjalan sesuai dengan hukum-hukum alam, dan diakui oleh hakikat yang bersumber pada biologi. ${ }^{4}$

Tujuan ini yakni, bahwa setiap manusia dengan individualitasnya mempunyai kepribadian dan beberapa ciri khas yang membedakannya dengan manusia lain. Pendidikan yang benar menurut mereka adalah yang menonjolkan ciri-ciri khas dengan jalan memberikan kebebasan kepada setiap manusia, memberikan waktu yang cukup dan menyediakan situasi yang sesuai bagi seluruh anak, agar setiap anak dapat merealisasikan kepribadiannya dalam suasana sosial yang sesuai dengan semua pihak.

Ada dua hal yang perlu ditanggapi berkenaan dengan tujuan ini; Pertama; bahwa kebebasan atau "aktivitas mutlak", sebagaimana diungkapkan oleh Bersey Nan, memerlukan beberapa pedoman yang menjaga setiap individu agar tidak tertipu oleh kepribadian mereka, menganiaya orang lain, atau menggunakan ciri khas kepribadian mereka dalam berbuat jahat terhadap umat manusia dan membahayakan masyarakat.

Kedua; bahwa kebebasan pribadi membutuhkan tujuan tertinggi yang terpadu dan direalisasikan oleh pribadi-pribadi ini, dengan tetap memberikan lapangan gerak kepada setiap pribadi untuk merealisasikan perbedaan individualnya. Hanya saja, dalam isyaratnya ini dia tidak bersandar kepada suatu prinsip atau standar kebaikan dan kejahatan. Kalaupun dia meletakkan suatu prinsip, pasti dalam hal ini dia akan berselisih dengan para pendidik dan filosof lainnya. Oleh sebab itu, harus ada standar ilahi yang membuat manusia sepakat terhadap materi ini. standar produk manusia berbeda-beda sesuai dengan perbedaan kondisi sosial, psikis dan keluarga mereka.

Mengenai bagaimana tujuan pendidikan Islam ${ }^{5}$ yaitu ikhlas beribadah kepada Allah. berhubungan dengan tujuan "merealisasikan kepribadian", sedangkan penjabarannya adalah sebagai berikut;

a. Allah mewajibkan manusia untuk beribadah kepadaNya, dengan pertimbangan bahwa manusia adalah makhluk yang mampu membedakan antara yang baik dengan yang jahat. Yang demikian itu karena Allah telah menjadikan makhluknya yang mampu membedakan dan memilih, yakni

${ }^{4}$ Nizar, Samsul.. Filsafat Pendidikan Islam: Pendidikan Historis, Teoritis dan Praktis (Jakarta: Ciputat Press, 2002)

${ }^{5}$ Muhaimin, Arah Baru Pengembangan Pendidikan Islam: Pemberdayaan, Pengembangan Kurikulum hingga rededifisi Islamisasi Pengetahuan (Bandung: Nuansa, 2010), hlm.13 
memberinya kebebasan memilih, kemudian menjelaskan tanggung jawabnya terhadap pemilihan ini.

b. Allah telah membukakan lapangan perlombaan seluas-luasnya bagi seluruh manusia untuk mengejar kebaikan, dan menjadikan prinsip pembalasan berdasarkan amal.

c. Allah menjadikan tujuan tertinggi, yaitu ketaatan dan ibadah kepada Allah. untuk standar antara yang baik dan yang jahat, telah dipaparkan di dalam kitab fiqih dan tauhid, serta dalam ayat-ayat al-Qur'an dan Hadits Rasulullah saw.

d. Dalam sebagian ayat dan Hadits Nabi, telah ditetapkan suatu tuntutan agar setiap manusia bekerja sesuai dengan kemampuan dan kesiapan kepribadiannya.

2. Islam dan Tujuan Perkembangan: Islam menumbuhkembangkan Berbagai Aspek Pendidikan.

Para sarjana dan filosof pendidikan dewasa ini berpendapat, bahwa satusatunya tujuan pendidikan adalah perkembangan manusia dari seluruh aspek; intelektual, fisik dan psikis. Tetapi makna perkembangan ini perlu dijelaskan: (1) apakah perkembangan hanya sekedar pertambahan besar, berat, atau (2) pertambahan ilmu pengetahuan dan pemikiran; ataukah (3) perkembangan itu berdimensi kualitatif bagi gaya hidup anak sejak lahir hingga baligh, di samping bagi aktifitas, tindakan dan tingkah lakunya?.

Para sarjana pendidikan sepakat, bahwa pertambahan kuantitatif saja bukan makna perkembangan yang dituju oleh pendidikan. Di samping kesepakatan ini, mereka berbeda pendapat tentang perkembangan tingkah laku manusia; Pertama: sebagian mereka mengatakan bahwa perkembangan itu berjalan secara otomatis dan hanya merupakan reaksi-reaksi reflektif. Mereka menjadikan manusia seperti mesin pabrik yang besar; jika salah satu tombolnya ditekan, maka bergeraklah salah satu alatnya dan setiap alat menggerakkan alat berikutnya.

Kedua: bahwa tingkah laku manusia berkembang berdasarkan pengalaman-pengalaman yang telah terbentuk padanya. Umpamanya, anak di tengah-tengah keluarganya. Ketika baju barunya kotor dengan makanan, mereka mencela, memarahi dan menampakkan di hadapannya kesan-kesan yang mempertalikan antara penyakit psikis dengan pengotoran baju baru. Hal ini menurut John Dewey dinamakan pengalaman. 
Pendidikan Islam yang meletakkan segala sesuatu pada tempatnya yang alami, memandang perkembangan dengan segala aspeknya sebagai alat untuk mencapai tujuannya yang paling tinggi, yaitu: beribadah dan taat kepada Allah serta melaksanakan keadilan dan syariatnya dalam seluruh urusan kehidupan individu dan masyarakat. Pencapaian ini memerlukan pembatasan dan penjelasan berikut;

\section{Pendidikan Islam dan Perkembangan fisik.}

Tidak diragukan, bahwa ketaatan, ibadah dan dakwah di jalan Allah, membutuhkan usaha keras dan kekuatan fisik. Islam menganjurkan perkara yang menguatkan fisik seperti memanah, menunggang kuda dan berenang. Pendidikan Islam mempunyai dua cara dalam mengarahkan potensi fisik: Pertama; mengarahkannya kepada segala yang diridloi Allah seperti menolong orang yang membutuhkan dan jihad di jalan Allah. Kedua; memperingatkannya dari segala yang dimurkai Allah, serta penganiayaan yang dilakukan oleh manusia siapa pun.

\section{Pendidikan Islam dan Perkembangan Intelektual}

Menurut pandangan Islam, akal merupakan kekuatan manusia yang paling vital. Oleh karena itu, seluruh rukun Iman didasarkan atas pemahaman akal. Al-Qur'an telah berbicara dengan akal guna membuktikan kepadanya atas adanya Allah. la mengajak manusia supaya berpikir tentang alam dan dirinya sendiri, guna membuktikan kepadanya bahwa hanya Allah-lah yang berhak disembah. Kemudian menyerukan supaya mengkiaskan membangkitkan di akhirat kepada penciptaan dan kejadian pertama, guna membuktikan dengan metode deduksi atas kebenaran akidah pembangkitan dan pembalasan. la memerintahkan supaya berpikir tentang penciptaan langit dan bumi, serta mempelajari jejak kaum terdahulu.

Pendidikan Islam mengembangkan akal agar berpikir sehat, merendahkan diri, tunduk kepada kebenaran, menjaga amanat ilmiah, mencari kebenaran tanpa menuruti hawa nafsu, menggunakan apa yang diketahui, dan tidak merasa puas dengan hanya memiliki ilmu teoritis. Pengetahuan saja tidak cukup, akan tetapi harus disertai dengan penerapannya. Meskipun pendidikan Islam tidak digariskan secara jelas untuk mengembangkan akal, namun tujuan akhirnya mencakup pengembangan intelektual dan fisik. Pengembangan aspek intelektual ini diarahkan kepada: (a) ketelitian dalam berpikir, menjaga amanat dan implementasinya, (b) usaha mengenal Allah pada ayat-ayat dan makhluk- 
Nya, (c) melihat petunjuk, jauh dari hawa nafsu dan ikut-ikutan secara buta, (d) mencari dalil dan pengetahuan yang yakin, dan jauh dari prasangka. ${ }^{6}$

\section{Pendidikan Islam dan Perkembangan Sosial.}

Tujuan pendidikan Islam mencakup aspek sosial yang merupakan salah satu aspek pendidikan;

a. Makna Perkembangan Sosial

Pendidikan sosial atau aspek sosial dalam pendidikan mempunyai banyak makna, yang terpenting ialah: (a) Perkembangan perasaan sosial, seperti perasaan bersandar dan kecenderungan fitriah kepada kelompok (ingroup, feeling), serta suka meniru. (b) Perkembangan pengalaman sosial dan segala implikasinya, seperti; cara berinteraksi dengan kelompok; pengetahuan tentang apa yang diharamkan, disukai dan diwajibkan oleh kelompok kepada setiap individunya dan bertingkah laku di dalam kelompok dan tata cara hidup bersama. (c) Perkembangan konsep sosial dan tujuan bersama yang lahir dari dalam jiwa setiap individu sebagai dampak dari pendidikan sosial yang mereka peroleh dan dari partisipasi dalam hari raya umat, penampilan hidup kelompoknya atau usaha-usaha perekonomian atau pembelaan agama dan Negara.

Anggota masyarakat non-muslim memperoleh tradisi dan konsepsi sosialnya melalui peniruan buta dan semangat membabi buta. Sedangkan pendidikan Islam mensyaratkan kepada setiap individunya supaya berfikir logis, menjaga kebersamaan kelompok dalam ibadah dan hari raya, berdasarkan kelogisan, kejelasan tujuan bersama, menjunjung tinggi tujuan ini.

b. Pendidikan Islam dan Warga Negara yang Baik.

Pendidikan Islam berbeda dengan pendidikan lain yang menjadikan tujuan perkembangan sosialnya dan tujuan pendidikan warga Negaranya ke arah pendidikan yang baik. Menurut mereka warga Negara yang baik adalah yang dididik dengan pendidikan sosial yang sesuai dengan masyarakat di mana dia tumbuh, serta yang merealisasikan berbagai kemaslahatan serta tuntutan masyarakat itu.

Oleh karena itu menciptakan warga Negara yang baik yang seiring dengan masyarakatnya dalam kebenaran dan kebathilan tidak pantas

${ }^{6}$ Muhammad al-Naquib al-Attas. Konsep Pendidikan dalam Islam (Bandung: Mizan, 1988) 
dijadikan tujuan pendidikan, tidak perlu untuk membentuk kehidupan sosial yang sehat dan konsepsi bersama bagi masyarakat yang lurus.

Oleh karena itu sikap Pendidikan Islam adalah mendidik warga Negaranya menjadi warga Negara mu'min dan masyarakat muslim agar dapat merealisasikan ubudiyah kepada Allah semata. Dengan terealisasinya tujuan ini, maka terealisasi pulalah segala keutamaan kehidupan sosial, seperti saling menolong, bahu membahu, menjamin dan mencintai. Di samping itu, pendidikan Islam juga menanamkan pada anak rasa butuh dekat dengan masyarakat, bersandar kepadanya, cenderung kepada tradisi dan merasa bangga dengan masyarakat.

Dengan kata lain, pendidikan Islam memadukan secara seimbang antara pendidikan kepribadian individual dengan pendidikan kecenderungan sosial. tidak memilih salah satu di antara keduanya, apalagi meremehkan yang lain, atau salah satu pihak menyimpang dari kebaikan dan ketaatan kepada Allah, dari perealisasian syariatNya, dan dari konsistensi dalam hidup.

\section{Pendidikan Islam dan Tujuan Mencari Rizki}

Banyak remaja yang belajar dan memasuki perguruan tinggi dengan maksud menciptakan lapangan kerja atau status sosial yang menjamin rizki mereka di kemudian hari. Tujuan ini memang disyariatkan, bahkan pendidikan yang mengabaikan tujuan ini akan mempersempit cakrawalanya, serta menghalangi manusia untuk mencapai keluhuran akhlak, berpikir dan berbudaya.

Oleh karena itu pendidikan Islam mengarahkan tujuan tersebut dan tidak pernah mengekang insting ini, yaitu insting mengumpulkan harta, keinginan untuk hidup senang dan kekal. Islam telah menjadikan pencarian harta sebagai salah satu alat ibadah dan pendekatan diri kepada Allah. Syaratnya ialah bahwa mencari harta itu dimaksudkan untuk memberi nafkah bagi keluarga, bagi dirinya sendiri.

\section{Kelebihan Tujuan Pendidikan Islam}

Tujuan pendidikan Islam mempunyai beberapa kelebihan, karena ia merupakan tujuan Rabbani. Sedangkan tujuan Rabbani mempunyai sifat-sifat sebagai berikut; ${ }^{7}$

1. Sempurna, kesempurnaannya bersumber pada kesempurnaan ilahi, kesempurnaan tersebut menjauhkan kita dari berbagai kekurangan di segala 
lapangan, serta mengarahkan kita kepada pencapaian berbagai keutamaan dan kebaikan insan, baik individu maupun masyarakat.

2. Luas, mencakup seluruh aspek kehidupan dan spikis insan.

3. Umum bagi seluruh manusia. Oleh karena itu, ia bersifat humanis, tidak khusus untuk kemaslahatan suatu umat atau bangsa tertentu saja.

4. Pantas untuk kekal dan abadi di setiap masa, karena ia datang dari Allah.

5. Sesuai dengan fitrah insan. Meski masa terus berlalu, namun fitrah manusia tidak akan pernah berubah, mengingat bahwa ia adalah individu, anggota kelompok, berasal dari darah dan daging serta mempunyai kecenderungan syahwat dan dorongan instingtif. la adalah manusia yang mempunyai akal, kehendak dan kemampuan untuk mengerjakan kebaikan atau kejahatan. Tujuan pendidikan Islam adalah mendidik seluruh kecenderungan, dorongan fitrah, kemudian mengarahkan semuanya kepada tujuannya yang tertinggi, menuju ibadah kepada Allah yang menciptakan manusia.

6. Subur, yang mengandung arti melahirkan buah yang baik.

7. Ia adalah tujuan yang jelas, difahami dan dimengeti oleh seluruh manusia. la sesuai dengan fitrah psikis dan intelektual berdasarkan atas indra dan kesadaran serta diterima oleh pendidik dan pelajar seluruhnya.

8. la adalah tujuan yang melahirkan keseimbangan dan meniadakan bentrokan antara aspek-aspek kehidupan dengan jiwa. Bahkan ia memadukan semuanya dalam satu tujuan yang mempunyai banyak cabang yang mencakup seluruh aspek ini.

9. Ia adalah tujuan yang realistis, mudah dilaksanakan, dan mempengaruhi tingkah laku seluruh manusia dengan perbedaan tarap perkembangan dan usia mereka.

10. Ia adalah tujuan yang fleksibel, mengikuti berbagai kondisi dapat mengikuti manusia di berbagai masa dan tempat. Fleksibilitas ini tidak akan terhalang oleh gaya hidup dan mata pencaharian yang berbeda. ${ }^{8}$

Persyaratan terpenting tujuan pendidikan ini telah dipenuhi oleh tujuan pendidikan Islam. Karena itu persyaratan tersebut menjadi ciri khas terpenting yang membedakan pendidikan Islam dengan pendidikan lain. Selain itu, itulah arah dan tujuan pendidikan Islam yang senantiasa mengidealkan hadirnya kemaslahatan, baik kemaslahatan vertikal (mencari keridlaan Allah SWT.) maupun

${ }^{8}$ M. Samsul Ulum, dkk., Tarbiyah Qur'aniyyah (Malang: UIN-Press, 2006), hlm. 57-59. Baca juga Abdurrahman Saleh Abdullah, Teori-teori Pendidikan Berdasarkan Al-Qur'an (Jakarta: Asdi Mahasatya, 2005), hlm.129. 
kemaslahatan horizontal (membangun keridlaan sesama manusia). Tekanan aksiologis pendidikan islam adalah memfokuskan dua arah kemaslahatan itu. Tujuan pendidikan yang mengantarkan manusia pada dua kepentingan, baik kepentingan profan maupun ukhrowi, kepentingan pragmatis maupun kepentingan esensialis, kepentingan jangka pendek maupun jangka panjang.

Sementara itu pendidikan Barat tidak memiliki arah aksiologis yang meliputi ranah kehidupan secara holistik. Orientasi pendidikan Barat hanya terjebak pada pemenuhan kebutuhan pragmatis/provan/jangka pendek dan menegasikan hal-hal di balik itu. Mereka hanya ingin membangun kesejahteraan diri mereka sendiri. Orientasi pendidikan demikian akan mengantarkan sikap individual dan sosial yang sangat egois. Keberhasilan dirinya adalah karena usaha keras dan jerih payah dirinya sendiri, bukan karena siapa-siapa. Pada saat yang sama mereka telah menegasikan peran manusia lain, lebih-lebih keterlibatan eksistensi dari Tuhannya. Tidak ada konsep syukur bagi mereka, selain bersyukur kepada diri mereka sendiri.

Secara sosiologis, mereka memang tidak berkenan mengganggu orang lain karena kesibukan orang lain tersebut. Sebaliknya mereka pun juga tidak ingin terganggu waktu dan kesempatannya oleh orang lain. Oleh karena itu di antara mereka saling cuek, tidak mau ikut mencampuri terlalu dalam terhadap rahasia kehidupan orang lain (sosial). Pola komunikasi mereka hanya sebatas pola komunikasi rasional, yaitu pola komunkasi yang saling menguntungkan secara ekonomis. Pola komunikasi yang jauh dari keterlibatan emosional yang mendalam, sebagaimana pola komunikasi yang dibangun dalam Islam. Pola komunikasi dalam Islam telah dikembangkan dan ditingkatkan hingga menyentuh pada misi profetik dan teologis. Dasar inilah yang telah melahirkan pola hubungan kemanusian dalam Islam telah diikat dengan pola kekeluargaan (ikhwah). Tidak hanya itu, pola kekeluargaan pun harus dibangun dengan landasan paradigma kasih sayang (rahmah).

Atas dasar itu, pendidikan apapun jenis dan modelnya, senantiasa sarat dengan arah dan tujuan profetik dan teologis, sebagai refleksi nilai-nilai yang harus melekat pada kepribadian mereka. Dengan demikian semakin tinggi kualifikasi pendidikan yang telah diperolehnya, maka semakin tinggi kesadaran spiritualitasnya (vertikal) dan etik/moralitasnya (sosial). 


\section{PENUTUP}

Sesuai dengan hasil analisis yang telah dilakukan dalam tulisan ini, perbedaan paradigma pendidikan Barat dan Islam tidak hanya terbatas pada ranah ontologis dan epistemologisnya, tetapi juga pada ranah aksiologis. Pada ranah konseptual ontologis ini, perbedaan pendidikan terlihat terutama pada ruang lingkup dan hakikat pendidikan itu sendiri. Barat membatasi ruang lingkup pendidikan pada wilayah-wilayah yang terlihat (empirik-positifistik), sementara Islam meliputi ruang lingkup yang lebih holistik, selain pada wilayah empirik (al-syahadah) juga pada wilayah makna (al-ghaib). Dari sinilah sebab munculnya akar filosofi perbedaan konseptual tentang hakikat pendidikan keduanya.

Sedangkan pada ranah epistemologis, perbedaan keduanya terletak pada sumber pengetahuan yang dicari serta cara dan strategi untuk menggali sumber pengetahuan itu. Barat membatasi sumber pengetahuan juga pada ranah-ranah empirik, yaitu pengalaman manusia, sementara itu Islam menjadikan sumber pengetahuan berasal dari basis nilai-nilai teks suci keagamaan sebagai sumber inspirasi keilmuannya. Belum lagi pada strategi apa yang dipakai keduanya untuk mencapainya.

Kelemahan Barat berkaitan dengan strategi mencapai sumber pengetahuan itu, banyak menggantikan peran subjek yang memiliki moral dan etik dengan subjek teknologi modern yang kering etika. Sementara dalam Islam masih memosisikan peran guru sebagai perantara transfer nilai yang dianggap masih substantif dalam proses pendidikan. Tentu dari ranah konseptual ontologis hingga proses pendidikan (epistemologis) yang berbeda ini akan berpengaruh secara langsung pada tataran aksiologinya. Secara aksiologis, Barat tidak menjadikan nilai-nilai sebagai bagian dari hasil pendidikan, sementara Islam basis nilai manjadi sebuah keniscayaan dan bagian yang tak terpisahkan dari hasil pendidikan itu sendiri.

\section{DAFTAR PUSTAKA}

Abdurrahman Saleh, Abdullah, 2005. Teori-teori Pendidikan Berdasarkan Al-Qur'an. Jakarta: Asdi Mahasatya.

Al-Attas, Muhammad al-Naquib. 1998. Konsep Pendidikan dalam Islam. Bandung: Mizan.

an-Nahlawi, Abdurrahman, 1989. Prinsip-prinsip dan Metode Pendidikan Islam. Bandung; Diponegoro. 
Fathoni, Muhammad Kholid, 2005. Pendidikan Islam dan Pendidikan Nasional (Paradigma Baru). Jakarta; DEPAG RI Direktorat Jenderal Kelembagaan Agama Islam.

Mansur. Dkk., 2005. Rekonstruksi Sejarah Pendidikan Islam di Indonesia. Jakarta; DEPAG RI Direktorat Jenderal Kelembagaan Agama Islam.

Mudzhar, Atho, H.M, 1998. Pendekatan Studi Islam, Dalam Teori dan Praktek, Yogyakarta, Pustaka Pelajar.

Muhaimin, 2009. Rekonstruksi Pendidikan Islam, Dari Paradigma Pengembangan, Manajemen Kelembagaan, Kurikulum hingga Strategi Pembelajaran. Jakarta; Raja Grafindo Persada.

Muhaimin, 2010. Arah Baru Pengembangan Pendidikan Islam: Pemberdayaan, Pengembangan Kurikulum hingga rededifisi Islamisasi Pengetahuan, Bandung: Nuansa.

Muliawan, Jasa Ungguh, 2005. Pendidikan Islam Integratif. Yogyakarta; Pustaka Pelajar.

Murtadha Muthahhari, 1993. Tema- Tema Penting Filsafat Islam, Terj. A. Rifa'i Hasan dan Yuliani L. Bandung: Mizan.

Nizar, Samsul, 2002. Filsafat Pendidikan Islam: Pendidikan Historis, Teoritis dan Praktis. Jakarta: Ciputat Press.

Tobroni, 2008. Pendidikan Islam, Paradigma Teologis, Filosofis dan Spiritualitas. Malang; UPT Penerbitan Universitas Muhamadiyah.

Ulum, M. Samsul, dkk., 2006. Tarbiyah Qur’aniyyah. Malang: UIN-Press. 